\title{
On the Problem of Contemporary Discourse in Linguistics
}

\author{
Olga V. Aleksandrova* \\ Lomonosov Moscow State University \\ 1 Leninskie Gory, Moscow, 119991, Russia
}

Received 04.12.2016, received in revised form 10.01.2016, accepted 23.01.2017

The article discusses how a new paradigm that emerged in linguistics on the brink of the 20th-21st centuries - cognitive linguistics - reborn the interest of scholars to the notion of discourse and the possibility of its definition and use of this term in modern linguistic research.

Keywords: discourse, communication, cognition, cognitive linguistics, context.

DOI: 10.17516/1997-1370-0037.

Research area: philology.

As we know, the term "discourse" has a massive history. Judging by the researchers, it appeared far back in the Latin language as "discursus" and meant "to run back and forth" that time (Demiankov, 2005). As a term discourse was reborn with the introduction of structural linguistics in the middle of the last century to nominate mainly the oral dialogical speech when linguists were in particular keen on the oral speech which had not been pretty much investigated before. In the end of the $20^{\text {th }}$ century the term became ingrained in all the humanities and political studies and still is keeping its triumphant progress on in different spheres of the human knowledge. How can we explain such a wide spreading of this term in different academic spheres, or, even, in our everyday life?

The end of the $20^{\text {th }}$ century was marked with the emergence of the new scientific paradigm: functionalism together with cognitive science were recognized as a new turn in linguistics. The performance of every new knowledge paradigm is invariably linked to reconsideration of those heritages which it gains from the previous paradigms and - mainly - from fundamental ideas comprising the topical area in science. Such situation has also influenced the definition of language per se within the cognitive science which considers it as an access arrangement to the brain's functions, mental activity and processes performed by the person.

Under the new paradigm the language is understood as a specific sign system which allows the human to treat their own kind for the purpose to exchange the information or to apply it any other way and provides us with different types of human behavior studies in general. Through this perspective the language

(C) Siberian Federal University. All rights reserved

* Corresponding author E-mail address: ovaleksandrova@gmail.com 
serves as whether the means to a certain cognitive end within communicative processes, or as a medium of communication aimed at the solution of particular communicative tasks. A constant relationship between cognition and communication alongside with their permanent interaction emphasized in this definition make us clarify a long-standing opinion that the language is interwoven into almost all the kinds of human activity and claim that in all these cases we actually observe a simultaneous performance of cognitive and communicative - or discursive - functions of the language. Differentiation and, particularly, opposition of the mentioned functions is entirely conventional and determined rather by epistemological focuses in researchers on such a complex object as the language, than by ontological circumstances. According to these views, to adequately characterize any linguistic phenomenon we must consider it "at the crossroads of cognition and communication" and discursive activity must, first and foremost, be defined as verbal and cogitative one.

Turning back to the term "discourse" per se, it should be noted that in the second half of the $20^{\text {th }}$ century it was addressed through the angle of its social and ideological meaning, not only the linguistic one (Pecheux, 1975). It was that time, when the researchers made their attempts to define the discourse and mark it off the text. There are numerous definitions for the term "discourse", still none of them is recognized as precise, complete and comprehensive. Indeed, is it really possible to adequately define this phenomenon? To quote only a few: E.S. Kubryakova notes that discourse is a term which covers not just a new linguistic reality, but even its higher reality (Kubryakova, 2004: 24) in the sense that it is discourse that stays at the top of linguistic hierarchy. Yu. S. Stepanov marks that discourse is also used to express a specific mentality and to depict and create unique "worlds'. V.Z. Demiankov points out that the "linguistic literature defines discourse as a speech (a text, in particular) within its formation in front of the addressee's cogitative view" (Kubryakova, 2004: 49).

The most popular linguistic definition of discourse was proposed by N.D. Arutyunova in the Linguistic Encyclopedic Dictionary where she describes the discourse as "a text dipped into the life" (Arutyunova, 1990: 136). We would not give the whole definition there since it has been published in the dictionary and besides we are sure that the reader perfectly knows it. Presumably, such an inclusive definition that allows analyzing discourse as a phenomenon going far beyond any philological frames has made it most acceptable for the wide range of researchers.

Indeed, at the turn of the centuries owing to a rapid development of the human knowledge it has become evident that any speech is in the diverse nature and can be interpreted and evaluated precisely basing on the context. As it has been mentioned before, a powerful impulse for the discursive studies development was given by the appearance and elaboration of the cognitive treatment of speech products. Of course, the problem on language-speech inter-relationship has long been in focus. Back to the 1930s, the world faced with the book by L.S. Vygotsky where for the first time he had raised this question and which actually had formed the basis for the language philosophy and psycholinguistics (Vygotsky, 1938). It is still obvious, that in those days, the science had not had enough knowledge about the human, but since the end of the $1950^{\mathrm{s}}$, it was increasingly intensifying the volume of its assets and, thus, moved to the next level cognitive approach to the language study that has been formed by the new century and is still evaluating.

It should be mentioned that the most significant stage in the language study is the switch of linguistics into a functional sphere under which 
we have distinguished and determined basic functions of the language, the most important of which are communicative and cognitive ones. As it is known, the functional researches of different linguistic schools contain various approaches; the national linguistic school considers cognitivity as a function of the language examination of which considerably expand the borders and possibilities of a comprehensive language study.

When the cognitive linguistics has come to the area, discourse has become one of its crucial concepts. It can be explained by the scientific interest towards different types of the speech arrangement, its recognition as a part of the human's mental activity. The studying of discourse directly involves the occurrence of new research areas, such, for example, as the conceptual view of the world and its reflection in the language, the problems of inference, intertextuality and etc. Certainly, discourse studies relate to the whole range of linguistic and speech phenomena, and, consequently there is a new paradigm for their analysis which E.S. Kubryakova called as a cognitive-discursive one (Kubryakova, 2004).

Many of the contemporary scholars note that the analysis of discourse is focused on the linguistic knowledge based on the level above words, phrases or sentences and, mainly, on the context of not only linguistic, but also extralinguistic nature. Thus, an English researcher $\mathrm{H}$. Widdowson gives the following example: a sign LADIES on the door (Widdowson, 2004). Can this word be a sentence and how do we understand its actual meaning, in what context and what does it refer to in our perception?

Of course, the language is not just a simple mirror reflection: the language reflects the world, but, at the same time, influences the environment around us. A fundamental point in the discursive analysis is that it considers the language as a basic part within the constructive human life perspective. In this sense, another interesting example is given by S. Bax, a British researcher: if an adult says to his child "school days are the best days of your life" (Bax, 2011: 30), it is not just a statement of the fact, but a particular element of the school-learning process construction within the adult's discourse made, perhaps, to encourage the child to attend classes and get good grades. Therefore, to examine the discourse it is considerably necessary to understand that the environment is created by the discourse which we use. L.Wood and R.Kroger mention that the main condition for the discursive analysis is that a socio-political world around us does not exists apart from us, from people, who create it (Wood, Kroger, 2000: 67).

To create a particular discourse we should take into consideration the following positions: what do we create a certain text for and what its goal is; how this goal is achieved and for what; what social context there will be as a space for the speech act. It is also important to identify its place and genre.

Let's take a small abstract from Steve Jobs's speech at the graduation ceremony in 2005. As we know, Steve Jobs is the Apple Mac Company's founder which in his running has taken the leading position in the digital world. He starts his speech in the following way:

I am honoured to be with you today at your commencement from one of the finest universities in the world.

This phrase contains a precise location that will be memorized by the graduates. At the same time, the author expresses his respect and love to the participants that is a crucial factor for any public speech. In this case the speaker establishes an emotional contact with the audience.

Further,

I never graduated from college. Truth be told, this is the closest I've ever gotten to a college graduation. Today I want to tell you 
three stories from my life. That's it. No big deal. Just three stories.

The last two sentences have been repeated three times within this small abstract, but each time - with a new purpose: at first, with the intention to introduce them to the audience, then to persuade the recipients to think over their meaning and, finally, to take leave.

This passage can be represented as an example of discursive analysis, since it is a part of the discourse, i.e. a part of what is happening within a particular period of time, in a certain place and audience in order to translate specific information to achieve a particular communicative goal.

Still, what is happening to discourse at the present time? If one opens any modern academic thesis or other publications, they will find the analysis of media-discourse, political, drama- or cinema-discourses and of many other types of this mysterious phenomenon.

Today, while, being influenced by sophisticated technologies, the language undergoes dramatic changes, the discourse studies obtain another importance since almost all the levels of the speech activity are interfered by significant transformations. Would the cognitivediscursive paradigm take a leading position in linguistics in the future or would there be a shift towards brand-new directions in the cognitive and communicative activity performed by the person - that is the question addressed by many scholars. Such situation is also a matter of concern to the linguists. In fact, the language always was, is and will be a key mechanism in the human life linked to all types of their activity and existence.

Under the modern paradigm of not only linguistic, but also universal knowledge, the discourse which cannot be precisely defined yet becomes a key notion. Or, even, should there be any definition within the system of current knowledge which is being broadened every day and which, presumably, is expected to give us new results in comprehension of the language existence and performance.

\section{References}

Arutyunova N.D. (1990). Diskurs [Discourse], In Lingvisticheskii entsiklopedicheskii slovar' [The Linguistic Encyclopedic Dictionary]. Moscow, Sovetskaia Entsiklopediia.

Demiankov V.Z. (2005). Tekst I diskurs kak terminy i kak slova obydennogo iazyka [Text and Discourse as Terms and Words of Everyday Language], In Iazyk. Lichnost'. Tekst: Sbornik k 70letiiu T.M. Nikolaevoi [Language. Person. Text: Collection Dedicated to the $70^{\text {th }}$ Anniversary of T.M. Nikolaeva]. Moscow, Iazyki slavianskikh kul'tur.

Kubryakova E.S. (2004). Iazykiznanie: Na puti polucheniia znanii o iazyke: Chasti rechi s kognitivnoi tochki zreniia. Rol' iazyka v poznanii mira[Language and Knowledge: On the Way to Gain Knowledge about the Language: Parts of Speech through the Cognitive Perspective. Role of the Language in the World Understanding]. Moscow, Iazyki slavianskikh kul'tur.

Vygotsky L.S. (1938). Iazyk i myshlenie [Language and Thoughts]. Leningrad.

Bax S. (2001). Discourse and Genre. Analysing Language in Context. Palgrave Macmillan.

Pecheux M. (1975). Les verities de la Palice. Linguistique, semantique, philosophie. Paris, Maspero.

Widdowson H. (2004). Text, Context, Pretext: Critical Issues in Discourse Analysis. Oxford, Blackwell.

Wood L., Kroger R. (2000). Doing Discourse Analysis: Methods for Studying Action in Talk and Text. London, Sage. 


\section{К вопросу о современном понимании \\ дискурса}

О.В. Александрова

Московский государственный университет

им. М.В. Ломоносова

Россия, 119991, Москва, Ленинские горы, 1

В статье рассматривается то, как новая парадигма, наметившаяся в лингвистических исследованиях на рубеже ХХ и ХХІ вв., когнитивная лингвистика возродила интерес исследователей к понятию «дискурс» и возможностям определения и применения этого термина в современной науке о языке.

Ключевые слова: дискурс, коммуникация, когнищия, когнитивная лингвистика, контекст.

Научная специиальность: 10.00.00 - филологические науки. 